\title{
Comparative study of two CAD software programs on consistency between custom abutment design and the output
}

\author{
Hyun-Mi Lim², Kyu-Bok Lee ${ }^{1,2 *}$, Wan-Sun Lee ${ }^{2}$, KeunBaDa Son ${ }^{2,3}$ \\ 'Department of Prosthodontics, School of Dentistry, Kyungpook National University, Daegu, Republic of Korea \\ ${ }^{2}$ Advanced Dental Device Development Institute, Kyungpook National University, Daegu, Republic of Korea \\ ${ }^{3}$ Department of Dental Science, Graduate School, Kyungpook National University, Daegu, Republic of Korea
}

\begin{abstract}
Purpose: This study was aimed to compare the consistency between the custom abutment design and the output in two CAD software programs. Materials and Methods: Customized abutments were designed by using 3Shape Dental System CAD software and Delta9 CAD software on a plaster model with implants (CRM STL file). After milling of the designed abutments, the abutments were scanned with a contact method scanner (Test STL file). We overlaid the Test STL file with each CRM STL file by using inspection software, and then compared the milling reproducibility by measuring the output error of the specimens from each CAD software program. Results: The Delta9 showed better milling reproducibility than 3Shape when comparing the milling errors obtained with a full scan of all specimens $(P<.05)$ and also when comparing the axial wall region specifically according to the axial angle. With 0.9 $\mathrm{mm}$ marginal radius, the Delta9 showed better consistency between the design and the output than 3Shape $(P<.05)$. While, antirotation form had no significant difference in error between the two systems. When cumulative errors were compared, the Delta9 showed better milling reproducibility in almost cases $(P<.05)$. Conclusion: Delta9 showed a significantly smaller error for most of the abutment design options. This means that it is possible to facilitate generation of printouts with reliable reproducibility and high precision with respect to the planned design. (J Dent Rehabil Appl Sci 2018;34(3):157-66)
\end{abstract}

Key words: CAD software; titanium custom abutment; precise reproducibility; 3D evaluation

\section{Introduction}

As the range of application of implant prostheses is expanding and the success rate is increasing, functional and aesthetic demands for restoration are diversifying. In fulfilling those demands, stock abutments have limitations such as the need for revision of the abutment shape, the deterioration of retention, the unnatural emergence profile and the risk of overfilling of the final prosthesis. Therefore, customized abutment is actively utilized. ${ }^{1}$ Advantages of the

*Correspondence to: Kyu-Bok Lee

Professor, Department of Prosthodontics, School of Dentistry, Advanced Dental Device Development Institute (A3DI), Kyungpook National University,

2177, Dalgubeol-daero, Jung-gu, Daegu, 41940, Republic of Korea

Tel: +82-53-600-7674, Fax: +82-53-427-0778, E-mail: kblee@knu.ac.kr

Received: April 3, 2018/Last Revision: May 19, 2018/Accepted: May 25, 2018
CAD/CAM abutment include the implementation of an optimized emergence profile, reduction of the risk of fracture of the final prosthesis by adjusting the thickness of the abutment upper prosthesis, freedom of margin positioning and ease of removal of excess cement. $^{2}$

In particular, it is known that the use of a customized abutment is an essential choice when the interocclusal space is insufficient; the implant needs to be angled more than $15^{\circ}$; when a collar height greater than $1 \mathrm{~mm}$ above the collar height of the stock abut-

CopyrightC 2018 The Korean Academy of Stomatognathic Function and Occlusion. (c) It is identical to Creative Commons Non-Commercial License. 
ment is required, parallelism is needed to achieve more than 3 unit restorations, or optimal soft tissue contours are required. ${ }^{3,4}$ In these cases, it is important that the abutment needs to be designed sophisticatedly as possible, and the designed values should be accurately embodied in the output CAD software.

In this study, we evaluated two recent CAD software programs for comparing their reproducibility of the customized abutment designed for various clinical conditions.

\section{Materials and Methods}

\section{Working model}

We used a working model in which an internal type implants (GS type, Osstem, Seoul, Korea) were implanted in the right maxillary first premolar, the right maxillary canine, the left mandibular first molar and the left mandibular central incisor. After placing the small size fixtures in the anterior and the regular size fixtures in the posterior regions, surrounding gingival shape was made by using a vinyl polysiloxane impression material (Examixfine, GC, Tokyo, Japan) (Fig. 1).

Using the data obtained by scanning (FREEDOM HD, DOF, Seoul, Korea) the working cast, customized abutments were designed for the right maxillary first premolar, right maxillary canine, left mandibular first molar and left mandibular incisors by using 3Shape Dental System CAD software (3Shape Dental System, Copenhagen, Denmark) and Delta9 CAD software (Delta9, Daesung, Seoul, Korea). In order to minimize deviation of the design of each specimen, two experimenters were assigned to each CAD software program. The CAD design of each abutment was named CAD-reference-model (CRM) and saved as a stereolithography (STL) file.

In this study, the design options are consists of three categories; axial wall angle, margin radius, antirotation form. Each options were applied to the custom abutment for 4 regions; mandibular incisor $\left(\mathrm{T}_{31}\right)$, maxillary canine $\left(T_{13}\right)$, maxillary premolar $\left(T_{15}\right)$ and mandibular molar $\left(\mathrm{T}_{36}\right)$.

Firstly, the inclinations of the abutment's upper portion (from margin to the top). The axial wall angles were divided into three groups of $2^{\circ}, 4^{\circ}$ and $6^{\circ}$ recommended for clinical applications and named $\mathrm{A}_{2}\left(\right.$ Angle $\left.^{\circ}\right), \mathrm{A}_{4}\left(\right.$ Angle $\left.^{\circ}\right)$ and $\mathrm{A}_{6}\left(\right.$ Angle $\left.^{\circ}\right) .^{5-10}$ Secondly, the margin radius. The margin radius was divided into two groups of $0.6 \mathrm{~mm}$ and $0.9 \mathrm{~mm}$. These two groups were named $\mathrm{R}_{6}$ (radius $0.6 \mathrm{~mm}$ ) and $\mathrm{R}_{9}$ (radius $0.9 \mathrm{~mm}$ ), respectively. ${ }^{11,12}$ The marginal curvature increases the margin width as the value increases. It is necessary to minimize the increase in the margin width in order to minimize the horizontal movement of the crowns due to the lateral force during mastication. That is why the minimum margin radius is $0.6 \mathrm{~mm}$ which can be obtained when milled with the diameter $1.0 \mathrm{~mm}$ milling bur used in the laboratory. The last category is the anti-rotation form. It was divided into two groups: the set group $(\mathrm{Y})$ and the unset group $(\mathrm{N})$. Twelve specimens were designed for each tooth with different set values (axial wall angle, margin radius, anti-rotation form) for all 4 restorations. The designed specimens were labeled TxAyRzY or TxAyRzN. In this paper, we designed 96 abutments for 48 scenarios, using both the Delta9 and 3Shape Dental System (Table 1).
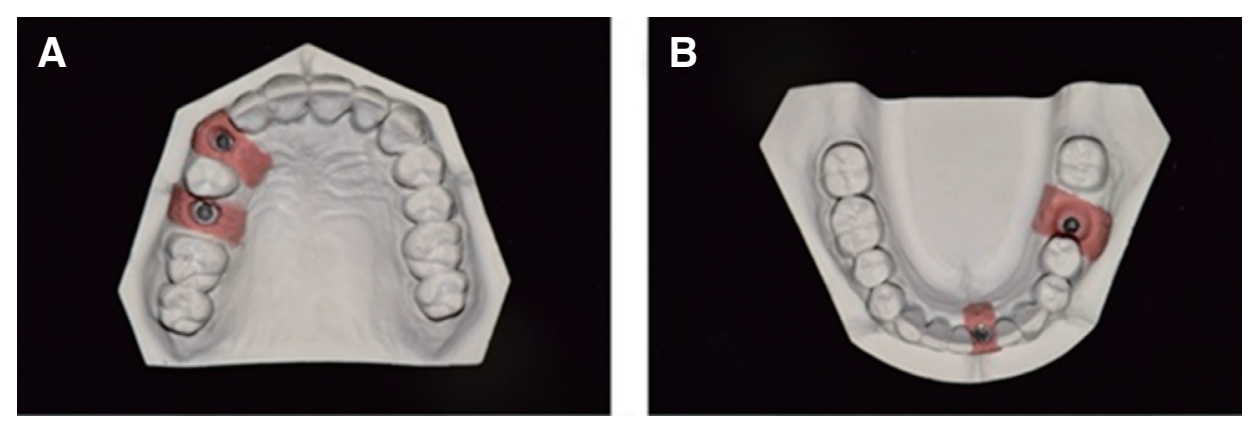

Fig. 1. Working model. (A) Maxilla, (B) Mandible. 
Table 1. CAD design options

\begin{tabular}{ccccc}
\hline Option items & $\begin{array}{c}\text { Tooth No. } \\
\text { (Tooth, } \mathrm{Tx})\end{array}$ & $\begin{array}{c}\text { Axial wall angle } \\
\text { (Angle, Ay) }\end{array}$ & $\begin{array}{c}\text { Margin radius } \\
\text { (Radius, Rz) }\end{array}$ & $\begin{array}{c}\text { Anti-rotation form } \\
\text { Y } / \mathrm{N}\end{array}$ \\
\hline & $31\left(\mathrm{~T}_{31}\right)$ & $2^{\circ}\left(\mathrm{A}_{2}\right)$ & \\
\\
$13\left(\mathrm{~T}_{13}\right)$ & $4^{\circ}\left(\mathrm{A}_{4}\right)$ & $0.6 \mathrm{~mm}\left(\mathrm{R}_{6}\right)$ & Yes $(\mathrm{Y})$ \\
& $15\left(\mathrm{~T}_{15}\right)$ & $6^{\circ}\left(\mathrm{A}_{6}\right)$ & $0.9 \mathrm{~mm}\left(\mathrm{R}_{9}\right)$ & No $(\mathrm{N})$ \\
\hline
\end{tabular}

\section{Data capturing \& processing}

The 5-axis milling machine (ARUM 5x-100, Doowon Inc., Daegeon, Korea) was used to mill the designed abutments with 1 set of $1.0 \mathrm{~mm}$ diameter milling burs per specimen. Then, we scanned the top of the output abutment with a contact method scanner (DS10, Renishaw, Gloucestershire, UK). Renishaw uses a probe to touch the object directly. It mechanically recognizes the shape line-by-line and obtains the information by converting the position value given by the ball and the coordinate values given by the three axes. In this way, the three-dimensional structure can be measured. ${ }^{13}$

In this study, we used a contact method scanner to reduce the thickness error due to the use of powder during scanning and to obtain the most accurate image. The contact type scanner used in the experiment scans the entire surface of the abutment by raising a ruby ball with a radius of $0.5 \mathrm{~mm}$ at the speed of $200 \mu \mathrm{m}$ per turn, which draws a spiral curve up the object from the bottom of the abutment fixed on the vertical support of the scanner. We performed error analysis after removing unnecessary parts of the scanned data by using a 3-dimensional (3D) analysis program (Geomagic Control X, 3D Systems, USA). ${ }^{14}$

The CRM STL file of each abutment was set as the control group, and the test STL file after the milling was designated as the comparative group. After initial alignment of each Test STL file with the CRM STL file of the same name, the Test STL file was converted into point clod data and rearranged into the surface data, CRM STL file, to achieve the best fit alignment. The point cloud was placed on the surface of the CRM STL file data, respectively. The distance between the surface data and all the correspond-
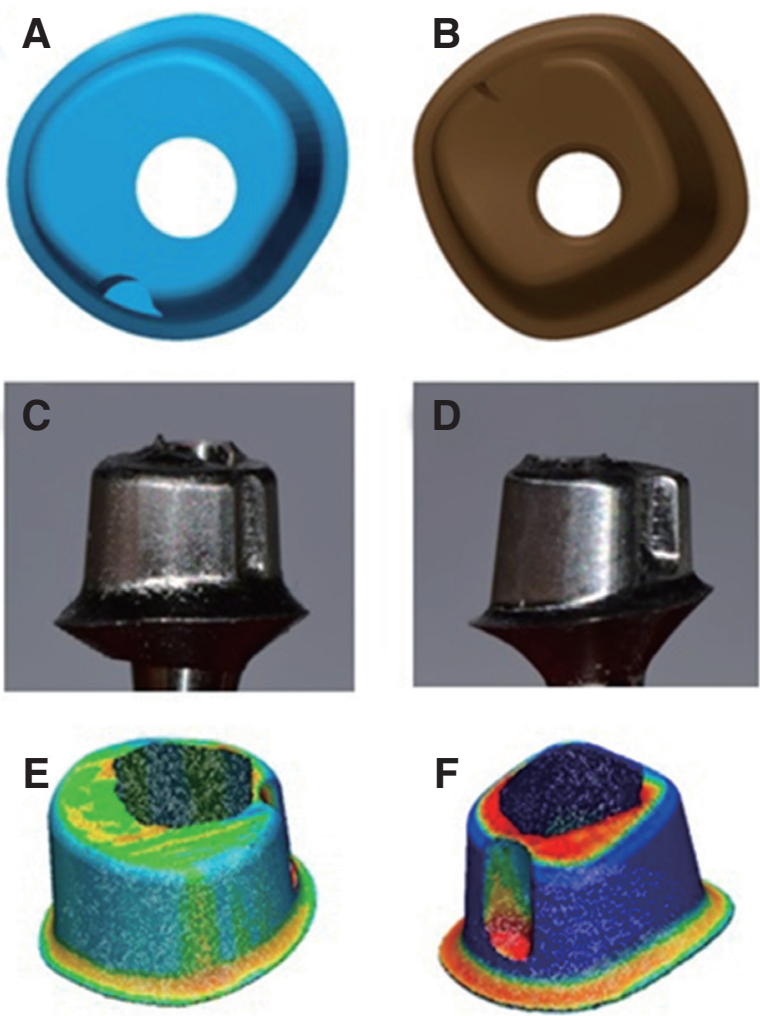

Fig. 2. $T_{36} A_{4} R_{9} Y$. Custom abutments for the left mandibular molar $\left(T_{36}\right)$ were designed having $4^{\circ}$ axial wall, $0.9 \mathrm{~mm}$ margin radius and anti-rotation form (CRM STL file: Delta9 (A), 3Shape Dental System (B)). Millin g process was done in accordance with CRM STL files (Delta9 (C), 3Shape Dental System (D)). C and D were scanned by using contact type scanner and the scanned data (Test STL file) were overlaid with each CRM STL file to do 3D analysis (Delta9 (E), 3Shape Dental System (F)).

ing points was converted into the root mean square (RMS) value to obtain the error average (Fig. 2).

In addition, we compared the differences in specific regions by performing local scoping separately to investigate the partial error range in three areas of the axial wall, the margin, and the anti-rotation form. 
We used RMS to check the error range. RMS is an average value mainly used for measurement error values in which both positive and negative values coexist, and the following formula was used: ${ }^{15}$

$$
\mathrm{RMS}=\sqrt{\frac{\sum_{\mathrm{i}=1}^{\mathrm{n}}(\mathrm{X} 1, \mathrm{i}-\mathrm{X} 2, \mathrm{i})^{2}}{\mathrm{n}}}
$$

$\mathrm{n}$ is the total number of specimens. $\mathrm{X}_{1, \mathrm{i}}$ are the measuring points of the control group, and $\mathrm{X}_{2, \mathrm{i}}$ are the measurement points of the experimental group. In this study, the error was evaluated by using the RMS value. According to International Organization Standard 12836, the lower the RMS value, the better the accuracy. ${ }^{16}$

In this study, abutment whole-body superposition and abutment partial region superposition were performed separately according to the design conditions by using the above-mentioned method. The milling reproducibility of the two CAD software programs was evaluated by comparing the measured milling error values.

\section{Statistical analysis}

All three-dimensional measurement data generated by superimposing CRM STL data and corresponding test STL data was analyzed using IBM SPSS Statistics 24 (SPSS, IBM Corp., Armonk, USA). The MannWhitney U test was performed to compare differences in anti-rotation form formation and margin curvature in each CAD software program. The KruskalWallis test was performed to evaluate the difference over the upper abutment angle. Post analysis was performed through pairwise comparisons. The statistical significance level was set at 0.05 .

\section{Results}

When superimposing the whole-body scan of specimens (from the margin to the top), CRM STL file and Test STL file, Delta9 showed better milling reproducibility in $T_{31}, T_{13}$ and $T_{36}$ groups than that of 3Shape (Fig. 3) $(P<.05)$. The main effect of tooth diameter were $\mathrm{F}=0.607, P=.613$, indicating that the $\mathrm{T}$ group and milling error were not significant for each CAD system. The main effect of the CAD software was $\mathrm{F}=35.698, P=.000$, and there was a significant difference between the two CAD software programs for milling error. The interaction effect was $\mathrm{F}=1.279, P=.288$, and there was no significant difference between the $\mathrm{T}$ groups by the type of CAD software $(P=.288)$.

When the axial milling error was compared according to A group, Delta9 had smaller error value in all cases. Taking a detailed look at $\mathrm{T}$ groups, $\mathrm{T}_{31}$ showed a significant difference between the two CAD software programs for the entire $A$ group, and the $T_{13}$ group showed a significant difference in $A_{2}$ and $A_{6}$, while the $T_{36}$ group had significant difference only for the $\mathrm{A}_{6}$ group (Table 2A).

In all cases, the mean milling in the margin region according to $\mathrm{R}$ group (margin radius) was smaller in 3Shape than that in the Delta9, but there was no significant difference between the $\mathrm{T}_{31} \mathrm{R}_{6}$ group and the $\mathrm{T}_{15} \mathrm{R}_{6}$ group $(P>.05)$ (Table $\left.2 \mathrm{~B}\right)$. The mean error value was smaller in $\mathrm{R}_{9}$ than in $\mathrm{R}_{6}$.

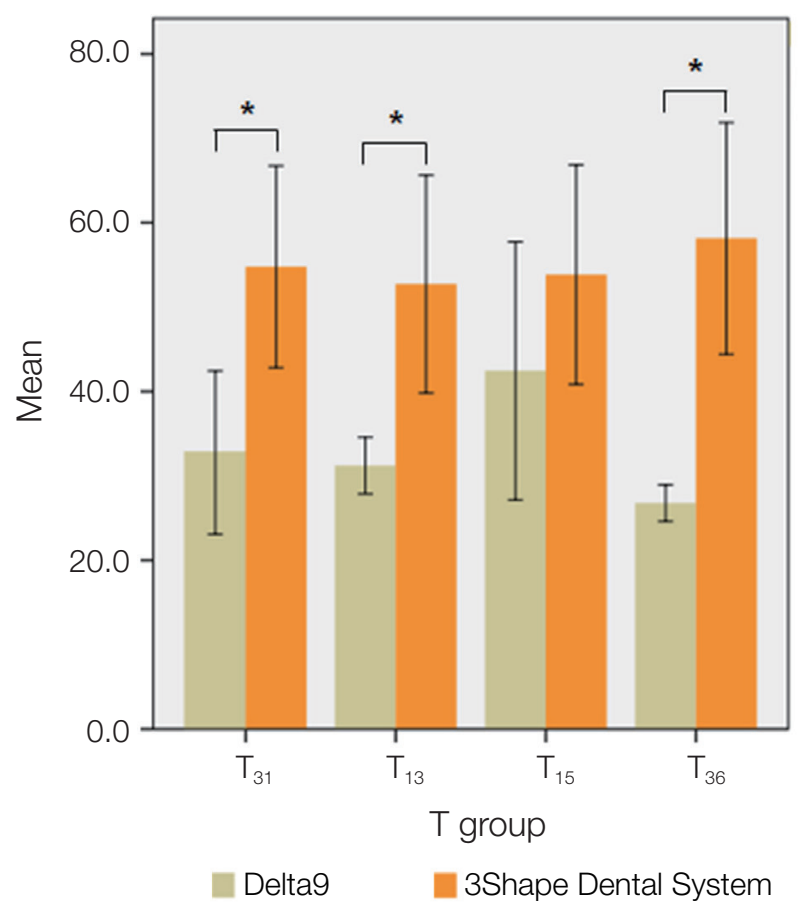

Fig. 3. Three dimensional error value of the abutments between the two CAD software programs (unit- $\mu \mathrm{m}$ ). 
The milling error in the form of anti-rotation did not show any significant difference between the two systems in all cases (Table 2C).

Finally, all specimens were divided according to A group in each CAD software, and every error values in three regions (axial wall, margin, anti-rotation) were cumulated by parts (Table 2D). The Delta9 showed better milling reproducibility at all most parts than 3Shape.

Table 2. Milling error values according to each design condition

\begin{tabular}{|c|c|c|c|c|c|c|c|c|c|}
\hline \multicolumn{10}{|c|}{ (A) Angle of the axial wall } \\
\hline Group & & $\mathrm{A}_{2}$ & & & $\mathrm{~A}_{4}$ & & & $\mathrm{~A}_{6}$ & \\
\hline System & Delta9 & $\begin{array}{l}\text { 3Shape } \\
\text { Dental } \\
\text { System }\end{array}$ & P & Delta9 & $\begin{array}{l}\text { 3Shape } \\
\text { Dental } \\
\text { System }\end{array}$ & $P$ & Delta9 & $\begin{array}{l}\text { 3Shape } \\
\text { Dental } \\
\text { System }\end{array}$ & $P$ \\
\hline Tooth & Mean \pm SD & Mean \pm SD & & Mean \pm SD & Mean \pm SD & & Mean \pm SD & Mean \pm SD & \\
\hline $\mathrm{T}_{31}$ & $7.1 \pm 0.8$ & $64.3 \pm 23.1$ & $.029 *$ & $9.2 \pm 3.7$ & $26.1 \pm 7.0$ & $.029 *$ & $7.5 \pm 2.1$ & $48.7 \pm 11.2$ & $.029 *$ \\
\hline $\mathrm{T}_{13}$ & $17.7 \pm 4.8$ & $67.4 \pm 19.4$ & $.029 *$ & $11.5 \pm 4.0$ & $14.3 \pm 3.8$ & .343 & $12.3 \pm 1.1$ & $38.1 \pm 13.9$ & $.029 *$ \\
\hline $\mathrm{T}_{15}$ & $39.1 \pm 11.6$ & $43.6 \pm 14.0$ & .686 & $24.2 \pm 7.7$ & $36.8 \pm 12.1$ & .114 & $29.9 \pm 18.2$ & $35.6 \pm 3.2$ & .343 \\
\hline $\mathrm{T}_{36}$ & $27.7 \pm 2.4$ & $27.7 \pm 3.3$ & .886 & $13.5 \pm 1.7$ & $33.5 \pm 22.4$ & .057 & $14.7 \pm 4.3$ & $45.5 \pm 10.9$ & $.029 *$ \\
\hline
\end{tabular}

(B) Margin radius

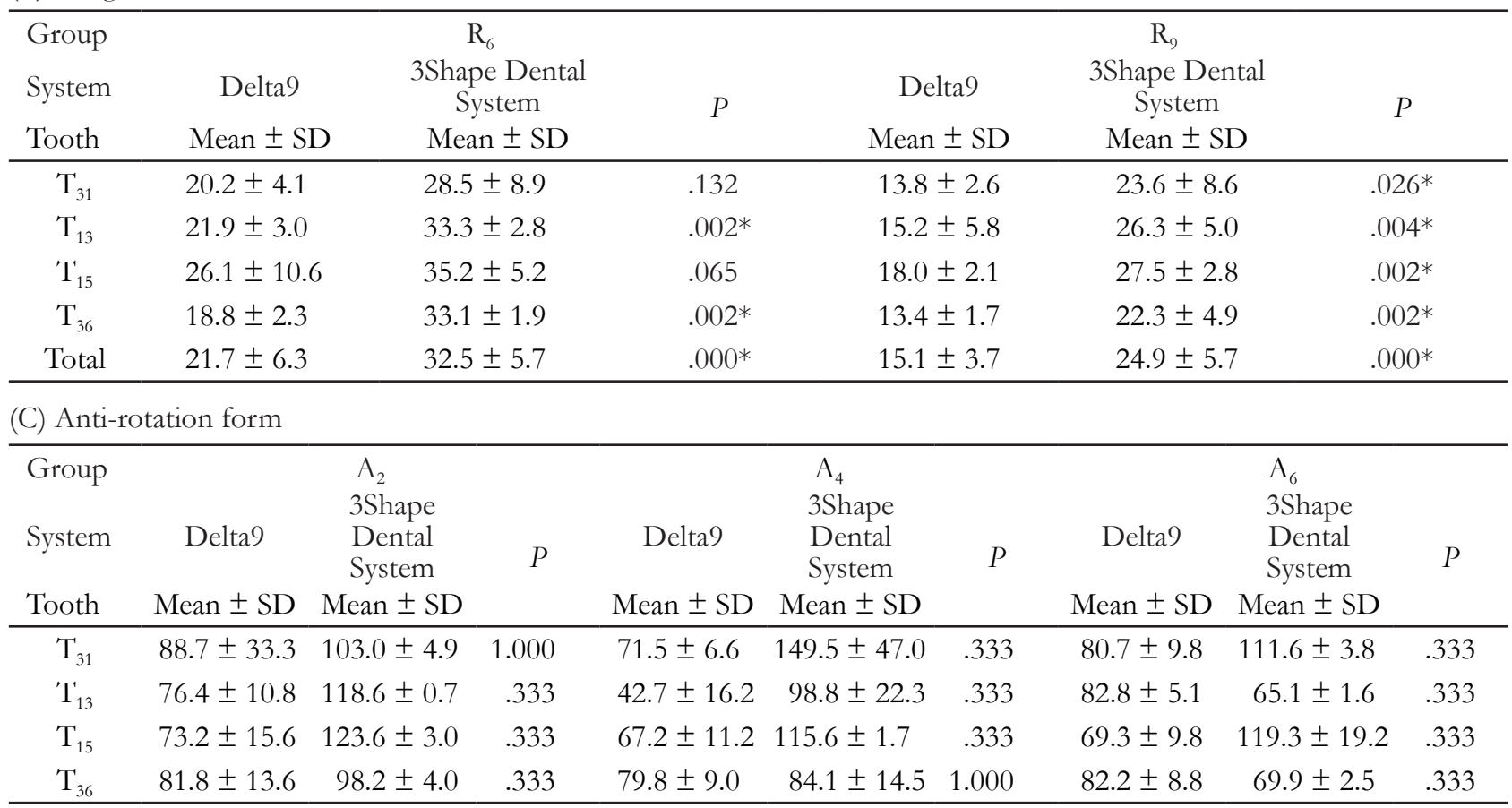

(D) Cumulative error vales in each CAD system

\begin{tabular}{|c|c|c|c|c|c|c|c|c|c|c|}
\hline \multicolumn{2}{|c|}{ Group } & \multicolumn{3}{|c|}{$\mathrm{A}_{2}$} & \multicolumn{3}{|c|}{$\mathrm{A}_{4}$} & \multicolumn{3}{|c|}{$\mathrm{A}_{6}$} \\
\hline \multicolumn{2}{|c|}{ System } & Delta9 & $\begin{array}{l}\text { 3Shape } \\
\text { Dental } \\
\text { System }\end{array}$ & $P$ & Delta9 & $\begin{array}{l}\text { 3Shape } \\
\text { Dental } \\
\text { System }\end{array}$ & $P$ & Delta9 & $\begin{array}{l}\text { 3Shape } \\
\text { Dental } \\
\text { System }\end{array}$ & \multirow[t]{2}{*}{$P$} \\
\hline Tootl & & Mean \pm SD & Mean \pm SD & & Mean \pm SD & Mean \pm SD & & Mean \pm SD & Mean \pm SD & \\
\hline \multirow{3}{*}{ Total } & $\begin{array}{l}\text { Anti-rotation } \\
\text { form }\end{array}$ & $80.0 \pm 16.6$ & $110.8 \pm 11.6$ & $.002^{*}$ & $65.3 \pm 17.1$ & $112.0 \pm 33.1$ & $.002^{*}$ & $78.7 \pm 8.8$ & $91.5 \pm 26.9$ & .721 \\
\hline & Axial & $22.9 \pm 13.5$ & $50.7 \pm 22.4$ & $.000^{*}$ & $14.6 \pm 7.3$ & $27.6 \pm 14.9$ & $.002^{*}$ & $16.1 \pm 12.1$ & $42.0 \pm 10.9$ & $.000^{*}$ \\
\hline & Margin & $20.8 \pm 8.9$ & $32.4 \pm 3.3$ & $.000 *$ & $17.6 \pm 3.4$ & $28.3 \pm 5.5$ & $.000 *$ & $16.9 \pm 4.0$ & $25.4 \pm 8.8$ & $.001 *$ \\
\hline
\end{tabular}

Mann-Whitney $U$ test, $*$ : Statistically significant, $P<.05$. 


\section{Discussion}

The object of this study was to verify the function of the two popular CAD software programs through evaluation of the milling reproducibility of the customized abutment designed by clinicians. For the Delta9, it showed a relatively smaller error value than that of 3Shape. However, it should be considered that this result came out from the limited and uncontrolled analysis conditions such as differences in margin width and anti-rotation shape and so on between the two CAD software programs. Errors in milling processes are not negligible as well.

Even though, in this study, it was supposed that the reproducibility of the output abutment is a representative value of that particular CAD software because the CAD software is programmed to satisfy the same design requirements of the experimenters as much as possible. That is why all output abutments can explain the performance of the CAD software to some extent.

To minimize error occurrence probability, several efforts were made in this study. Firstly, contact type scanner was chosen in scanning process, the touch probe has a good accuracy because it touches the object directly and acquires all the measurement points. On the other hand, since the touch probe must contact the surface of the object, it may deform or damage the object. In addition, it has a limited ability to measure sharp spikes due to the round shape of the touch probe. ${ }^{17}$ However, Persson et al. reported that a touch probe is highly efficient. They compared the accuracy and stability of each scanner by using a dental contact method scanner and a non-contact laser scanner. Software was used to overlap the results and produce three-dimensional digital models of each abutment. In both scanners, small errors of less than $10 \mu \mathrm{m}$ were observed. The contact type scanner was more accurate and stable, and in qualitative evaluation. Moreover, contact type was more efficient in reproducing the edge surface than the laser scanner when scanning edges such as the margin. ${ }^{18}$

Secondly, to reduce processing errors occurring in estimating partial region-specific analysis, such as lacking consistency in setting partial regions (axial wall, margin, anti-rotation form), we also compared the error values of the whole upper part of the abutments. That could enhance the best fit alignment in the overlapping comparison. Delta9 from the wholebody scan was analyzed by $\mathrm{T}$ groups, which showed that better milling reproducibility can be obtained through the use of Delta9 software in real clinical practice (Fig. 3).

In order to investigate the difference in error sensitivity between CAD software programs according to the partial design setting of the abutment, the error was divided into three parts: axial wall, margin, and anti-rotation form. When we compared the error values of the axial wall according to the A group except for $\mathrm{T}_{36} \mathrm{~A}_{6}$, the smaller the implant diameter of the area to be restored, the more significant the difference between the two CAD software programs was. It is expected that the difference in the shape of output abutments from each system becomes more apparent as the diameter of the implant becomes smaller. Since the axial line angle of abutment using the 3Shape Dental System is smaller than the Delta9, this may result in accumulated errors during the milling process or during the contact process of the round tool used for rescans. In particular, when designing the anterior teeth and cusps using the 3Shape Dental System, more delicate work will be required considering the possibility of milling errors.

The axial wall milling error of the $T_{15}$ group was not significantly different between the two systems under all conditions. Further research is needed to determine whether the effects of design, implant area, and height are offset and minimized when working on the premolar site. On the other hand, Delta9 software shows higher milling error values than other parts in all of the same axial wall angle conditions in the abutment design of the premolar region. It should be supplemented with further research on whether there is a site-specific error in the software programs.

As a result of the measurement of the milling reproducibility according to the marginal radius, the milling error of all CAD systems was smaller at $\mathrm{R}_{9}$ than at $R_{6}$. This is because these gentle curves have the advantage of reducing the error in the scanning 
process by allowing the touch probe to more closely contact the implant. When a $0.9 \mathrm{~mm}$ margin radius was applied $\left(\mathrm{R}_{9}\right)$, the 3 Shape Dental System showed greater milling error in all $\mathrm{T}$ groups than that of Delta9 $(P<.05)$. When the same margin curvature was applied, the curvature given by the 3Shape Dental System to the design might be different from that of the actual milling bur. It is not possible to exclude the possibility that the margin width is set wider than the Delta9 when designing using 3Shape Dental System software, which can increase the error value by providing more surfaces to be estimated. The Delta9 has an automatically set margin width through numerical input, while the 3Shape makes margin by manual drawing.

When the anti-rotation form was created, the milling error values were not significantly different between the two CAD systems in the all A groups. Even though, anti-rotation form has the highest absolute error value among all variables in this study, it seems not cause a significant difference in the total error of each specimen. For that reason, the formation of an anti-rotation form is clinically acceptable.

Considering many papers that show that the formation of the anti-rotation form is a necessary factor to improve the retention of the prosthesis and the error value in their studies is in a clinically acceptable range, the use of anti-form rotation design in the CAD software programs in this study can be considered acceptable. Sahu et al. ${ }^{19}$ reported that they have achieved tensile bone strength of about 2.5 times higher than smooth surfaced milled abutments. In an evaluation of the factors affecting the retention of the standard titanium implant abutments of Eklinget et al., ${ }^{20}$ they noted that the retention increases with an increasing anti-rotation plane.

Finally, the errors of the abutments were integrated by the CAD system, and the milling errors of the three (axial wall, margin, anti-rotation form) CAD systems were further compared according to the A group (Table 2D). In actual clinical practice (except in special circumstances), it is the axial wall angle that is the most frequently designated as the design setting value directly by the clinician. That is why we classified and compared the errors according to the
A group to investigate the effect of axial wall angle on the milling error. Delta9 showed significantly better reproducibility regardless of axial wall angle, except in the A6 group.

In this study, there were uncontrolled factors during process, which might affect the result some to extend. It could be called as a limitation.

Firstly, since the design of the custom abutment was different due to the differences in the set range of the tools provided in each experimental CAD software program, it was not possible to make a through comparison of the milling error values between the two CAD software programs for each specimen. Therefore, we tried to interpret the data with a focus on qualitative analysis.

Secondly, the overall shape of the specific custom abutments of each CAD software program results in a difference in the total surface area, and the larger the area becomes, the greater the possibility that the error value increases.

Finally, the error values were presented by overlaps between the CRM STL file and the Test STL file, and the tendency was analyzed. These are unavoidable errors that were measured during the course of the experiment: errors in designing, milling bur wear, errors in generating STL file transformation, actual errors when nesting two STL files, as well as errors due to insecurity in array. The effect of these factors on the experimental results cannot be ruled out. ${ }^{15,21}$

\section{Conclusion}

Depending on the design conditions, some settings did not show significant differences; however, in most of the abutment design options (axial wall angle, margin radius, anti-rotation form) applied in this experiment, Delta9 showed a significantly smaller error value. This means that the consistency between custom abutment design and the output of Delta9 was similar to or better than 3Shape. Therefore, it is more likely that clinicians will get printouts with reliable reproducibility close to the design they have planned with Delta9. 


\section{Acknowledgements}

This work was supported by Institute for Information \& Communications Technology Promotion (IITP) grant funded by the Korea government (MSIP) (B0101-17-1081, Development of ICT based software platform and service technologies for medical 3D printing applications) and Industrial Strategic Technology Development Program (10062635, New hybrid milling machine with a resolution of less than $10 \mu \mathrm{m}$ development, using open CAD/CAM S/W integrated platforms for one day prosthetic treatment of 3D smart medical care system) funded By the Ministry of Trade, Industry \& Energy (MOTIE, Korea).

\section{ORCID}

Hyun-Mi Lim https://orcid.org/0000-0001-9700-5673

Kyu-Bok Lee https://orcid.org/0000-0002-1838-7229

Wan-Sun Lee https://orcid.org/0000-0002-4410-5854

KeunBaDa Son https://orcid.org/0000-0002-3177-8005

\section{References}

1. Kim JW, Heo YR, Kim HJ, Chung CH. A comparative study on the fit and screw joint stability of ready-made abutment and CAD-CAM custommade abutment. J Korean Acad Prosthodont 2013; 51:276-83.

2. Priest G. Virtual-designed and computer-milled implant abutments. J Oral Maxillofac Surg 2005;63:2232.

3. Alshhrani WM, Al Amri MD. Customized CADCAM healing abutment for delayed loaded implants. J Prosthet Dent 2016;116:176-9.

4. Thulasidas S, Givan DA, Lemons JE, O'Neal SJ, Ramp LC, Liu PR. Influence of implant angulation on the fracture resistance of zirconia abutments. J Prosthodont 2015;24:127-35.

5. Vinnakota DN. Effect of preparation convergence on retention of multiple unit restorations-An in vitro study. Contemp Clin Dent 2015;6:409-13.

6. Corazza PH, Feitosa SA, Borges AL, Della Bona A.
Influence of convergence angle of tooth preparation on the fracture resistance of Y-TZP-based allceramic restorations. Dent Mater 2013;29:339-47.

7. Tiu J, Al-Amleh B, Waddell JN, Duncan WJ. Reporting numeric values of complete crowns. Part 2: Retention and resistance theories. J Prosthet Dent 2015;114:75-80.

8. Shillingburg HT, Sather DA, Wilson EL, Cain JR, Mitchell DL, Blanco LJ, Kessler JC. Fundamentals of fixed prosthodontics. 4th ed. Hanover Park; Quintessence; 2012. p. 132-3.

9. Alghazzawi TF. Advancements in CAD/CAM technology: options for practical implementation. J Prosthodont Res 2016;60:72-84.

10. Yamanishi Y, Yamaguchi S, Imazato S, Nakano T, Yatani H. Effects of the implant design on periimplant bone stress and abutment micromovement: three-dimensional finite element analysis of original computer-aided design models. J Periodontol 2014;85:e333-8.

11. Komine F, Iwai T, Kobayashi K, Matsumura H. Marginal and internal adaptation of zirconium dioxide ceramic copings and crowns with different finish line designs. Dent Mater J 2007;26:659-64.

12. Beuer F, Aggstaller H, Edelhoff D, Gernet W. Effect of preparation design on the fracture resistance of zirconia crown copings. Dent Mater J 2008;27:362-7.

13. May KB, Russell MM, Razzoog ME, Lang BR. Precision of fit: the Procera AllCeram crown. J Prosthet Dent 1998;80:394-404.

14. Kim CM, Jeon JH, Lee JJ, Kim JH, Kim WC. Precision evaluation of crown prosthesis manufactured by two bur and three bur. J Korean Acad Dent Tech 2016;38:57-62.

15. Schaefer O, Watts DC, Sigusch BW, Kuepper H, Guentsch A. Marginal and internal fit of pressed lithium disilicate partial crowns in vitro: a three-dimensional analysis of accuracy and reproducibility. Dent Mater 2012;28:320-6.

16. International Organization for Standardization. ISO-12836:2015. Dentistry - digitizing devices for CAD/CAM systems for indirect dental restorations - Test methods for assessing accuracy. Available from: https://www.iso.org/standard/68414.html 
(updated 2018 Sep 12).

17. Lee GT, Kim JH, Kim WC, Kim JH. Three-dimensional evaluation on the repeatability and reproducibility of dental scanner-based digital models. J Korean Acad Dent Tech 2012;34:213-20.

18. Persson A, Andersson M, Oden A, SandborghEnglund G. A three-dimensional evaluation of a laser scanner and a touch-probe scanner. J Prosthet Dent 2006;95:194-200.

19. Sahu N, Lakshmi N, Azhagarasan NS, Agnihotri Y, Rajan M, Hariharan R. Comparison of the effect of implant abutment surface modifications on reten- tion of implant-supported restoration with a polymer based cement. J Clin Diagn Res 2014;8:239-42.

20. Enkling N, Ueda T, Gholami H, Bayer S, Katsoulis J, Mericske-Stern R. Precision of fit and retention force of cast non-precious-crowns on standard titanium implant-abutment with different design and height. Clin Oral Implants Res 2014;25:451-7.

21. Huh JB, Shim JS. The factors caused errors in the production process of CAD/CAM prosthesis based on experience. J Korean Dent Assoc 2014;52: 332-45. 


\section{두 가지 CAD software의 맞춤형 지대주 디자인과 출력물 일치도 비교}

\section{임현미 $\left.\right|^{1,2}$, 이규복 ${ }^{1,2 *}$, 이완선 ${ }^{2}$, 손큰바다 ${ }^{2,3}$}

${ }^{1}$ 경북대학교 치과대학 치과보철학교실

${ }^{2}$ 경북대학교 첨단치과의료기기개발연구소

${ }^{3}$ 경북대학교 대학원 치의과학과

목적: 두 가지 CAD software에서 각 software의 맞춤형 지대주 디자인과 출력물의 일치도를 비교 평가한다.

연구 재료 및 방법: 3Shape Dental System과Delta9 CAD 소프트웨어를 이용하여 임플란트 식립 석고모델에 맞춤형 지대 주를 디자인하였다(CRM STL file). 디자인한 지대주를 밀링 한 후, 접촉식 방식으로 스캔하고(Test STL file), Inspection 소프트웨어에서 각 지대주의 Test STL file과 CRM STL file을 중첩하여 오차값을 측정하였다.

결과: 시편의 전체 스캔 오차 비교와 축면 경사각에 따른 축면부위 오차비교에서 Delta9이 더 나은 밀링 재현성을 보였 다 $(P<.05)$. 마진설정 시, 반경 $0.9 \mathrm{~mm}$ 에서 Delta9의 디자인과 출력물의 일치도가 더 우수했다 $(P<.05)$. 반면, Antirotation 형태 부여에 따른 유의할 만한 차이는 없었다. 부위별 오차 값 누적 비교에서는 Delta9이 대부분의 시편에서 더 작은 오차 값을 보였다 $(P<.05)$.

결론: Delta9이 대부분의 디자인 설정 환경에서 3Shape보다 더 작은 오차 값을 보였다. 이는 Delta9을 사용했을 때, 계획 된 디자인과 출력물의 일치도가 3Shape과 유사하거나 더 좋은 출력물을 얻을 수 있음을 의미한다.

(구강회복응용과학지 2018;34(3):157-66)

주요어: $\mathrm{CAD}$ 소프트웨어; 타이타늄 맞춤 지대주; 재현 정확성; 3D 평가

*교신저자: 이규복

(41940)대구광역시 중구 달구벌대로 2177 경북대학교 치과대학 보철학교실, 경북대학교 첨단치과의료기기개발연구소(A3DI)

Tel: +82-53-600-7674 | Fax: +82-53-427-0778 | E-mail: kblee@knu.ac. kr

|접수일: 2018년 4월 3일 | 수정일: 2018년 5월 19일 | 채택일: 2018년 5월 25일 